\title{
The TPM-Kurtilas Implementation Program of Children's Behavioral Changes in Kindergarten
}

\author{
Bellanita Maryadi, Aan Listiana, Yeni Rachmawati, Badru Zaman \\ Universitas Pendidikan Indonesia, Bandung, Indonesia \\ Corresponding e-mail: bellanitamaryadi1263@gmail.com
}

\begin{abstract}
The article aims to describe the result of TPM-Kurtilas Implementation program in changing children's behavior in Bunda Balita Kindergarten. The writing of this article is based on the importance of input as a further revision program of TPMKurtilas in its pilot study. The method conducted in this study is qualitative approach using teacher's interview, teacher's field note, observer's field note and teacher's reflection note as collection data techniques in the implementation of TPMKurtilas made in thematic analysis. The result showed that the children in BB Kindergarten expressed a positive behavior changes especially in discipline, polite manners because of the presence of learning environment setting. The study concludes that a condusive learning environment setting which was implemented TPM-Kurtilas result in good impact through children's behavioral changes namely discipline and polite manner.
\end{abstract}

Keywords: TPM-Kurtilas, Children's behavior

\section{INTRODUCTION}

In Indonesia, Criminal cases which involved children as the actor and the victim have increased significantly since 2014 . This violence can occur within families, schools and even in our communities. KPAI Monitoring and evaluation results indicated that in $2012,91 \%$ of children are victims of violence in the family, $87.6 \%$ in the school environment, and $17.9 \%$ in the community (KPAI, 2014). The data indicates that children are vulnerable to become a victim and also an actor of violence at home and at school environment in which the environment is immediate environment of children.

The case above if not addressed sooner would become terrible thing and get bad impact for children's life in the future as a pride generation. Therefore, preventive effort urgently required to reduce such violence happened to our children whether as victims or as actors. One of the efforts is by giving character education since early childhood. Based on Taiwan's research, the character education must be given as early as possible beginning from elementary level or even at pre-school level. This study becomes the proposal to the need of character education in pre-school setting (Chou, Yang \& Huang, 2014). Ferdiawan \& Putra (2013) also stated that early childhood is a sensitive period to build child's personality.

In fact, character education has not reached optimally applied especially in early childhood institution. The teacher has not planned and designed this character education as systematic and as integrated as well. This is proven by the observation result from the previous researcher that teacher designed the instructional program which focus only on academic skill such as reading, writing, and counting (Mumun, 2009; Fuadah, 2013; Muhartini, 2013; Giyatni, 2013; Arie \& Rakhmawati, 2014).

One of the basic children's character development program that can be used as a learning program alternative is children's basic character development program through the Teaching Pyramid Model which based on 2013 curriculum (TPMKurtilas) designed by Listiana, et.al. (2015). The teacher could implement this model as one of solutions to develop children's character by its 
planned, systematic, and comprehensive program. This model is an adaptation of Teaching Pyramid Model (TPM) by Lise (2003) and 2013 curriculum.

The aim, material, and evaluation designed by this TPM-Kurtilas is one of the adaptation model which combined with 2013 curriculum. Meanwhile the learning strategy is adapted from the four TPM implementation steps (Fox, et.al, 2003): developing positive supportive relationships with the children, setting a condusive learning environment, teaching social and emotional skills, and giving individual's needs for those children who have more intensive needs. Thus, this TPM-Kurtilas program is a combination of 2013 curriculum and Teaching Pyramid Model (Listiana \& Rachmawati, 2016). Below is the description of TPM-Kurtilas Construction:

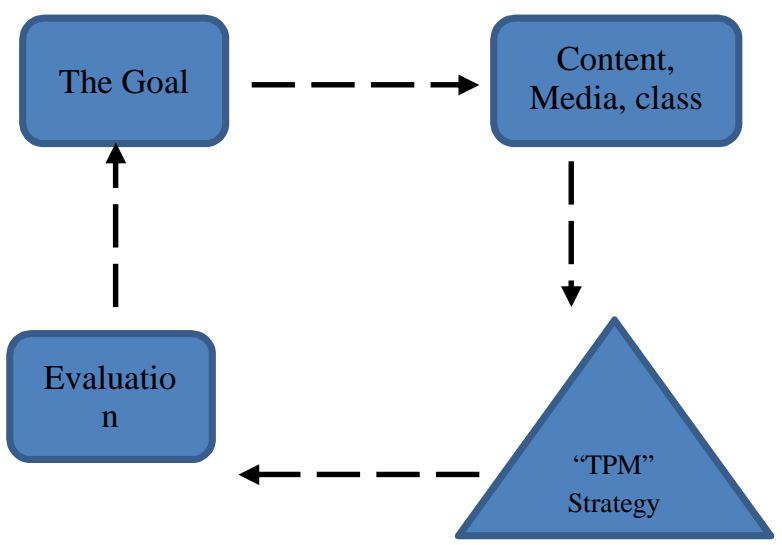

Figure 1. TPM-Kurtilas Model, Listiana \& Rachmawati (2016)

A previous research conducted with regards this teaching pyramid model is the research by Lise Fox, et.al. (2003) that implied TPM as a model that supports in developing children's social competence and preventing deviant behavior. Not long after that, Fox \& Lentini (2006) studied the second step of pyramid model in teaching children's social and emotional skills. Hemmeter, et.al. (2006) tried the relation of TPM with child's school readiness. The next research conducted also by Fox, et.al. (2010) and Hemmeter (2011) which focus on teacher's training for implementing the TPM program. Then, a study about the relation between TPM and RtI (Response to Intervention) by Fox, et.al (2010) and also other TPM study for toddler level done by Branson \& Demchak (2010).

The research is part of a series of Pilot studies on TPM-Kurtilas implementation in several kindergarten in Bandung, West Java. As for TPM-
Kurtilas research that has been conducted before is in the formulation of TPM-Kurtilas model (Listiana \& Rachmawati, 2016), Teacher's Perception of the implementation of TPM-Kurtilas (Listiana \& Rachmawati, 2016), and the Effectiveness of TPMKurtilas Implementation (Listiana \& Rachmawati, 2016). Then this article will discuss the changing of children's behavior after TPM-Kurtilas implementation in Bunda Balita Kindergarten.

TPM-Kurtilas as a model which still in a pilot phase requires a lot of input for future improvements. The article tries to reveal the result of TPM-Kurtilas implementation in changing children's behavior. Then, the purpose of this article is to describe children's behavior that arise along the implementation of TPM-Kurtilas program.

\section{METHOD}

The research was conducted in qualitative approach. The data obtained in the field by interviewing 3 teachers, teacher's field note, observer's note, teacher's reflection's note of TPM-Kurtilas program. The research held in Bunda Balita Kindergarten with 7 students as participants. That analysis data technique is in thematic analysis as the identification of the themes that are plotted in a phenomenon (Boyatzis, 1998). The implementation process of TPM-Kurtilas carried out every day in four months from February-May 2016 at the beginning of the learning process with 30 minutes duration. The material given in this TPM-Kurtilas is related to the social and spiritual attitude. Social attitude includes healthy life, curiosity, creative, aesthetic, confidence, discipline, self-reliance, caring, cooperating, adaptive, honest, humble, and polite. Meanwhile, in spiritual attitude manners such as the acceptance of the belief espoused.

\section{FINDINGS AND DISCUSSION}

The data obtained descriptively from teacher's interview, teacher's field note, observer's note, and teacher's reflection note on TPM-Kurtilas implementation indicates that children's behavior after the implementation of TPM-Kurtilas program for about 4 months since February-May at the beginning of each lesson for about 30 minutes overall exhibit behavioral change towards a better tendency. But after looking at the data, there are two most prominent's children behavior changes: discipline and polite manners. 


\section{Discipline}

Based on the interview, the teachers stated that after TPM-Kurtilas implementation, the children become more disciplined, orderly in following the rules especially when children sit down and store the goods. The teachers explains honestly that the application rules in discipline and politeness for children at school have been applied previously in such of warning without media usage. As a result, there are differences teaching methods for applying discipline in TPM-Kurtilas program. The teachers said that the use of Children's photographs and children's name are effectively used to make children easier in storing the goods in accordance with its place. The following interviews of teachers who supported the above conditions:

"Actually the program is used to be done in Bunda Balita, but without media usage"

(Interview of teacher 1, 09 June 2016).

"Essentially, the children follow the regulations, and praise to God, now is beginning to be more increased than before."

"Sitting in the chair eating, I saw the children can directly follow the rules, so... it's my seat, I can sit here...then where sandals are given names and photos of that too, they are happy and so orderly in saving it, it is definitely there to keep it." (Interview of teacher 1, 09 June 2016).

Then the observer's note that supported the above conditions are:

"Children are always directly store their bag in a locker without being reminded" (Observer's note, Desi Amalia, 10 May 2016).

"Children are accustomed to storing bag and shoes in place" (Observer's note, AP, 16 May 2016).

Based the teacher's interview and observer's note described above, the existence of names and photos of the children is considered as one of the things that makes the children in orderly storing the goods and sits neatly. This is to help teachers in guiding children to become faith without being reminded repeatedly. In TPM-Kurtilas strategy, this condition is part of setting a conducive learning environment strategy. Creating a conducive learning environment is one of the efforts to change classroom setting based on the children's needs in helping children to understand what they should do, such as giving the names and photos in every children's seat, locker, bag's rack, and shoe rack (Listiana, et.al. (2016)

Blagojevic (2011) stated that the use of photograph and a name tag is one of visual supports in learning. Photos and name tag could help children in knowing what to do, learning a new skill, making the children got involved more. Besides that, when applying the rules visually in daily routines, the children will do the monitoring of their own behavior by seeing the posters and the pictures that remind them of the existing regulations (CSEFEL, 2010). This visual strategy is appropriately applied in early childhood setting rather than to only give verbal rules to children without any visual media. It is also supported by the results of the research conducted by the British Audio Visual Association in Zaman (2005) which explained that the information obtained of $75 \%$ through the sense of sight (visual), 13\% through the sense of hearing, and $6 \%$ through the sense of touch/palpation.

\section{Polite manners}

In addition to discipline behavior, the other notable behavior is politeness especially in greeting and knocking on the door as the children entered the room and manners while eating. Before it, teachers has already taught manners to the children such as greetings, but they did not use media, only by reminding the children verbally. Teachers assume that the existence of poster from TPM-Kurtilas program could make children consistent in doing something. Below is teacher's interview that supported the above condition:

"I knocked on the door and say:

Assalaamu'alaikum...yeah... Assalaamu'alaikum is as usual, then when I was late also says Assalaamu'alaikum...but when reading the poster, you knocked this and that...but the children also sometimes did not say at first, like a shy child who greet the teacher outside the class, teacher says:" Say salam...then you have to say what???, the child replied: "Assalaamu' alaikum...then after that Praise to God the children realized that before saying Assalaamu'alaikum, they have to knock the door at first. The poster is trully helpful", teacher replied. (Interview of teacher 3, 14 June 2016).

Teacher arguments above reinforced by other teachers' argument that expressed:

"Assalaamu'alaikum is the most prominent, and when eating...they remind each other to not talking during meals" (Interview of teacher 2, 14 June 2016).

In addition, there are the results of teacher's reflection notes on the implementation of TPMKurtilas supporting evidence of polite manners from the children: 
"Such as entering the room by knocking on the door at first and say 'Hello' and nearly all the children already get used to apply it. Even if there's someone who forgets, they are easily reminded. There is even a direct repeat after realizing their forgetfullness before teacher's reminded". (Teacher's reflection, Mrs.Nn, 29 June 2016).

Meanwhile, the results of other teachers' reflection are aligned with respect to this children's polite manners:

"Children also used to entering the classroom with a greeting, sometimes if the children forgot, they will come back out and repeat it as they knocked on the door then say hello. Besides that, the children also easier to get reminded of the rules, such as when children are a bit of noise, the teacher or even other students reminiscent the regulations by pointing out to the meal's poster" (Teacher's reflection on the TPM-Kurtilas program, Mrs.Wn I J, 29 June 2016).
As for the results of observer's note which entailed children's polite manner is as the following:

"The children also get used to knocking on the door and say "Assalaamu'alaikum" as they entered the room” (Observer's note, DA, 11 May 2016).

Concerning the above data presented, it can be concluded that one of the behaviors that stand out after the implementation of TPM-Kurtilas is in politeness manner such as knocking on the door when they entered the room, say hello (Assalaamu'alaikum), and do not talk while meals. This behavior appeared as a result from the presence of poster media including the poster of entering the room, the poster of table manner, and learning attitude. This poster presents a conducive learning environment which has been previously described. The poster made for this TPM-Kurtilas has its own characteristics in which involved the image of cue points in each of its rules.

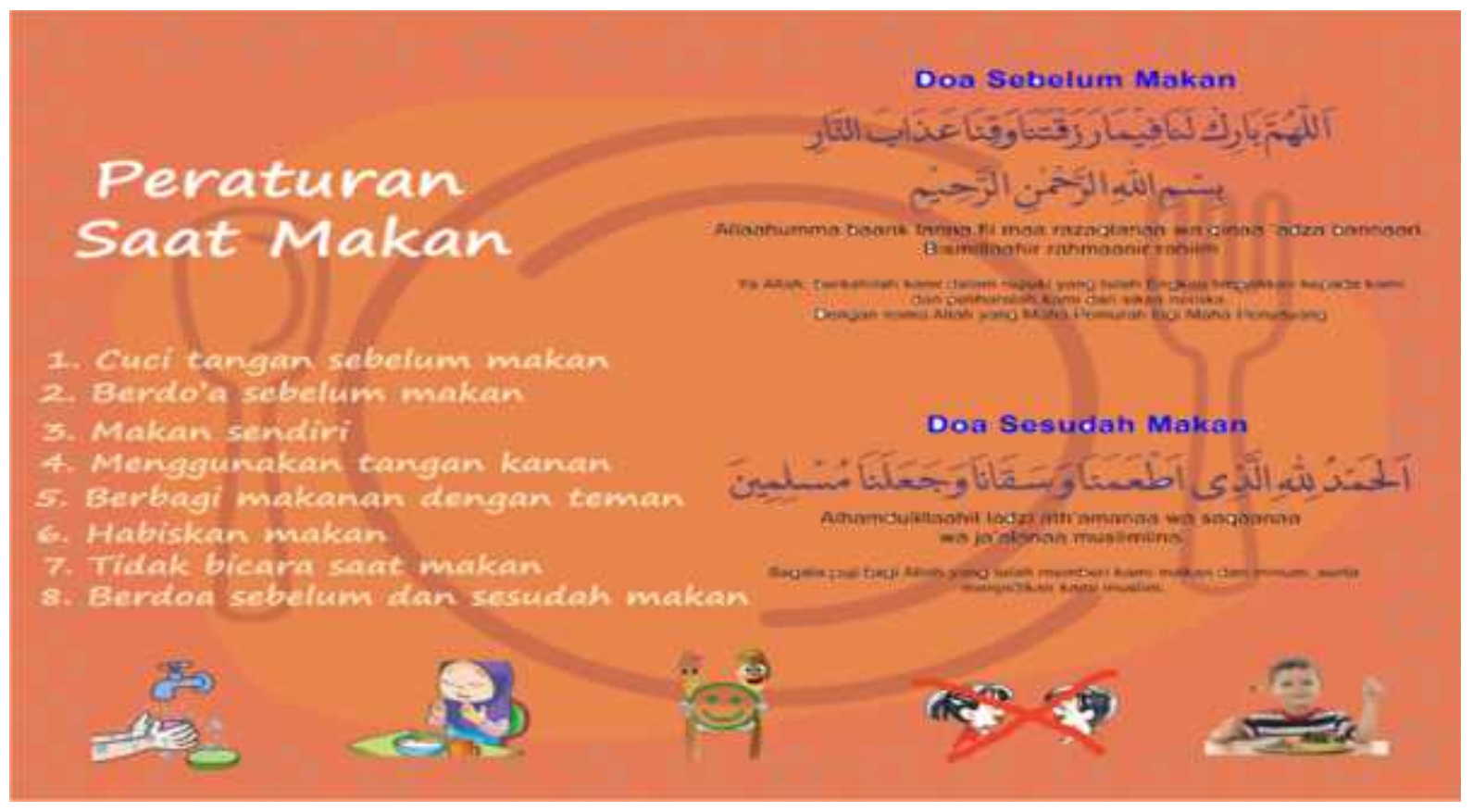

Figure 2. Current rules Eating 


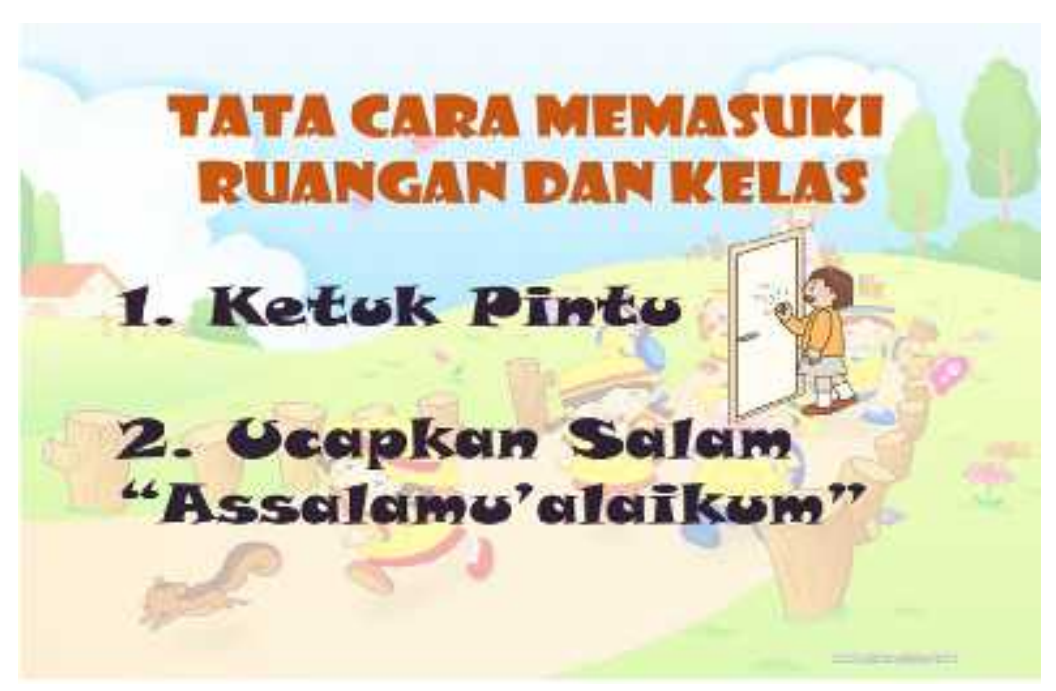

Figure 3. Procedures for Entering the Room

Poster picture cues or known as Visual Cues Instruction is a written instruction involving images, photos, or symbols representing body language, location, and environment. Visual Cues Instruction has certain benefits in helping children to improve organization skill, academic instruction, communication, socialization, and self-control (Hawkins \& Clayton, 2011). The importance of this visual cues in instruction is also stated by Murphy (2013). He mentioned that children in studying an instruction requires a behavior that can be seen, so that children can internalize their feelings to such behavior.

In terms of expert opinion above, theoretical evidence revealed that behavioral changes in politeness as it has exhibited by the children in Bunda Balita Kindergarten could be caused by the presence of poster regulations that involves visual cues. This is because the children become easier to learn and understand the behavior or instruction on what is expected by the teacher to the children's action in accordance with the regulations.

Furthermore, the children also become easier in translating a written regulation which still in an abstract image into a concrete behaviors that children can see and understand. So, the poster media becomes an appropriate medium to be applied based on the stages of development revealed by Piaget in Santrock (2007) that early childhood is pre-operational phase in which children learn to use real and concrete objects.

The efforts that have been made by TPMKurtilas to develop children's basic character which one of the purposes is to develop discipline and polite manners have compatibility with the ways initiated by Ki Hajar Dewantara (education figure in
Indonesia) in educating the children. Ki Hajar Dewantara argued that in educating children takes five specific ways that need to be considered including: 1) Giving an example (Voorbeelt); 2) Habituation (pakulinan, gewoontevorming); 3) Teaching (wulang-wuruk); 4). Conduct (zelfbeheersching); 5) Physic and mental experience (nglakoni, ngrasa), Ki Hajar Dewantara in High Court Unity-Assembly of Taman Siswa, 1977).

The education ways mentioned above is appropriate to build children's character and in line with TPM-Kurtilas program. Starting from the teaching of the school's regulation (wulang-wuruk) by poster usage to the children, followed by the application (zelfbeheersching), then habituation in children's daily activities (pakulinan), and eventually the children will have the experience and accustomed to comply with the regulations that have been taught (nglakoni, ngrasa).

\section{CONCLUSIONS}

Based on the findings and discussions above can be concluded that the implementation of TPM-Kurtilas have demonstrated behavioral changes in children. The most notable change behavior is the behavior of discipline and polite manners. This can be seen from the children who consistently store the objects in accordance with its place, sits neatly, and doing polite manners like knocking on the door as they enter and say greetings, as well as child's manners while taking meals. The teacher assumed that the most influential factors of children's behavioral changes is the usage of photos and posters. The researcher suggests for the completion of the 
program by creating media images and posters to teach children's behavior or new skills based on the children's needs ultimately by using a material that is more robust, not easily broken, so the photos and posters can remain in a good condition. In addition, the implementation of TPM-Kurtilas must be extended in the time allocation that allowed children to get an optimum stimulation of character education. The suggestion also gives to the next researcher to investigate the obstacles encountered when the teachers implemented TPM-Kurtilas as the input for a better future improvements program.

\section{REFERENCES}

Arie \& Rakhmawati, (2014). Upaya meningkatkan kecerdasan interpersonal melalui metode Cooperative play pada kelompok B di Daqu School International: Jurnal Penelitian PAUDIA

Blagojevic, et. al.(2011) Take a look! Visual Support for Learning. Picturing good Practice Teaching Young Children 4(5). NAEYC

Boyatzis, E. Richard. (1998). Transforming Qualitative information: Thematic Analysis and Code Development. Sage:London

Branson, D., \& Demchak, M. (2010). Toddler Teachers' Use of teaching Pyramid practices. Early Childhood Special Educatin, 30(4), 196208

Chou, Mei-Ju, yang, Chen-Hsin, Huang, \& PinChen. (2014). Keindahan Pendidikan karakter di Prasekolah Anak. Taiwan: Universitas Shoufu Taiwan.

CSEFEL (2010). Module 3b: Tips and Ideas for Making Visual to Support Young Children With Challengging Behavior.. Vanderbilt University. H3b. 2 P $1 / 7$

Ferdiawan, E. \& W.P. Putra. (2013). ESQ Education for Children: Character Building Based on Phylosophy of Javaness in Indonesia. Procedia, social and Behavioral Sciences, 106. 1096-1102

Fox, L., \& Lentini, R. H. (2006). " You Got It!" Teaching Social and Emotional Skills. YC Young Children, 61(6), 36.

Fox, L., Carta, J., Strain, P. S., Dunlap, G., \& Hemmeter, M. L. (2010). Response to intervention and the pyramid model. Infants \& Young Children,23(1), 3-13.

Fox, L., Dunlap, G., Hemmeter, M. L., Joseph, G. E., \& Strain, P. S. (2003). The Teaching Pyramid: A Model for Supporting Social
Competence and Preventing Challenging

Behavior in Young Children. Young

Children, 58(4), 48-52.

Fox, L., Hemmeter, M. L., Snyder, P., Binder, D. P., \& Clarke, S. (2011). Coaching early childhood special educators to implement a comprehensive model for promoting young children's social competence. Topics in Early Childhood Special Education, 31(3), 178-192.

Fuadah, H.L. (2013). Mengembangkan Kecerdasan Spiritual Anak Usia Dini melalui Pembelajaran dengan Metode Cerita Islami. (Skripsi). Fakultas Ilmu Pendidikan, Universitas Pendidikan Indonesia, Bandung.

Giyatni, (2013). Mengembangkan kecerdasan interpersonal melalui metode bermain peran pada kelompok B melalui metode Brmain Peran TK Al Irsyad. Jurnal Publikasi: Surakarta Universitas Muhammadiyah

Hawkins \& Cathy. (2011) Using Visual Cues toImprove Classroom Instruction for Young Children with Developmental Delays. Atlanta: Assistive Technology Dept. Fulton County School

Hemmeter, M. L., \& Fox, L. (2009). The Teaching Pyramid: A model for the implementation of classroom practices within a program-wide approach to behavior support. NHSA DIALOG, 12(2), 133-147.

Hemmeter, M. L., Ostrosky, M., \& Fox, L. (2006). Social and emotional foundations for early learning: A conceptual model for intervention. School Psychology Review, 35(4), 583.

Hemmeter, Mary Louise, et al. "Professional development related to the teaching pyramid model for addressing the social emotional development and challenging behavior of young children." International Society on Early Intervention Conference, New York, NY. 2011.

Ki Hadjar Dewantara. (1977) Bagian Pertama: Pendidikan. Yogyakarta: Majelis Luhur Persatuan Taman Siswa

Komnas Perlindungan Anak Indonesia, (2014). Anak Terlibat Kriminalitas Karea terinspirasi Lingkungan Tak Ramah Anak. [Online]. Diakses dari http://www.kpai.go.id.com. 27 April 2016

Listiana, A., Rachmawati, Y., (2016). Pengembangan Model TPM-Kurtilas: Adaptasi Teaching Pyramid Model dalam Kurikulum 2013 Guna Pengembangan Karakter Anak Usia Dini. Bandung: PGPAUD UPI 
Listiana, dkk (2016). Pedoman Umum Program

Pegembangan Karakter Melalui teaching

Pyramid Model Berdaarkan Kurikulum 2013.

Bandung: Universitas Pendidikan Indonesia

Mumun, S. (2009). Pengembangan kecerdasan interpersonal anak. (Skripsi). Sekolah Tinggi Agama Islam Negeri, Pekalongan

Murphy (2013). The Power of Visual learning and Storytelling in Early Childhood Education. Boston: Pearson

Santrock, J.W. (2007). Life-Span Development: Perkembangan Masa Hidup (edisi kelima).(Penerj. Achmad Chusairi, Juda Damanik; Ed. Herman Sinaga, Yati Sumiharti). Jakarta: Erlangga.

Zaman dkk. (2005). Media dan Sumber Belajar TK. Jakarta: Universitas terbuka 